\title{
Micro-Economic Determinants of NAV of Islamic Equity Unit Trust Funds in Malaysia: An ARDL-Bounds Tasting Approach
}

\author{
Anwar Hasan Abdullah Othman \\ Department of Business Administration \\ International Islamic University Malaysia (IIUM) \\ PO Box 53100, Kuala Lumpur, Malaysia \\ E-mail: anwar315a@yahoo.com \\ Ahamed Kameel Mydin Meera \\ Department of Business Administration \\ International Islamic University Malaysia (IIUM) \\ PO Box 53100, Kuala Lumpur, Malaysia \\ E-mail: akameel@iium.edu.my \\ Hasanuddeen Abdul Aziz \\ Department of Business Administration \\ International Islamic University Malaysia (IIUM) \\ PO Box 53100, Kuala Lumpur, Malaysia \\ E-mail: ahassan@iium.edu.my
}

Received: July 10, 2014 Accepted: August 2, 2014 Published: January 1, 2015

doi:10.5296//jmr.v7i2.7051 URL: http://dx.doi.org/10.5296/jmr.v7i2.7051

\section{Abstract}

The increasing importance of the Islamic unit trust industry requires a more detailed and 


\section{Macrothink

efficient analysis on the various aspects of the industry. The purpose of this study, therefore, is to investigate the relationship between the NAV of the Islamic equity unit trust funds and microeconomic variables, namely fund dividends, fund Risk, fund historical performance, fund size, fund management experience and hedge fund investment in Malaysian unit trust industry. The analysis based on monthly closing price for a sample of 30 Islamic equity unit trust funds over a period of 7 years, from January 2006 to December 2012, by applying ARDL - bounds testing approach. The results indicate that the NAV of Islamic equity unit trust funds and its microeconomic determinants share long run relationship, but with two variables exception, which are the fund risk and fund management experience. This indicated that fund's managers in the Malaysian unit trust industry performed poorly in security analyses (stock selection ability) and market entry timing. Hence, the study proposes that the fund's managers have to focus on and sharpen their abilities of timing skills and stock selecting ability in order to achieve a better performance of their activities in prudently managing their portfolio investments. However, fund managers performed fairly well in risk-adjusted returns and typically maintained well-diversified portfolios. Therefore, the empirical result of this study may present the investors (unit-holders) with new prospective of making right decision investment when they come to select their fund as a part of their portfolio investment. This could be done through considering the microeconomic factors that found to be significantly influence the funds unit prices to either enhance their portfolio return or to mitigate their portfolio risks when they make decisions to invest in the Malaysian unit trust industry.

Keywords: Microeconomic Factors, NAV, Equity Unit Trust Fund, Malaysia 


\section{Introduction}

The Islamic unit trust investment refers to the marketplace where the activities are carried out in ways that do not conflict with the ethics of Muslims and the religion of Islam. In other words, the Islamic unit trust scheme emphasizes the need to transact their business to strictly adhere to the Islamic tenet scrupulously. The SC of Malaysia has rigorously established the major requirements for the purpose of launching the Islamic fund management entity. Firstly, the fund manager is required to appoint an independent Shari ah Advisor who has the requisite advisory capacity to provide an exclusive service to the Shari ${ }^{\prime}$ ah experts to guide on all relevant matters closely related to the Islamic fund management business. Secondly, the Islamic fund manager is vested with the obligation that the Shari ${ }^{-}$h principles should at all times be rigorously observed and complied with when the financial businesses are being performed through the portfolio management service (Lexis Nexis, 2009). Thus, Muslim capital seekers and capital providers can have a clean conscience when investing in the Shari ${ }^{\prime}$ ah compliant capital market as an alternative to the conventional unit trust investment.

In addition, the validity, in terms of Shari ah compliances, will always be subjected to two basic conditions: Firstly, instead of a fixed return tied to the shares' face values, it must carry a pro-rata profit actually earned by the funds. In other words, before entering the unit trust fund investment, the unit-holders must be made to be fully aware of the fact that the actual profit earned or lost suffered by the fund is undetachably linked to their investments without any ambiguity. Secondly, the amounts pooled together must be invested in a business acceptable to the Sharīah guidelines (Usmani, 2002).

In general, the selections of the Shari ${ }^{\prime}$ ah-compliant companies are based on the screening process using two reliable approaches, namely, the qualitative and the quantitative parameters (Sadeghi, 2008). The qualitative parameter looks into the core activity of the business and the structure of the transaction in terms of whether there is any element that is prohibited by the Islamic law. This include interest (riba), uncertainty (gharar), gambling (Maysir or Qimar), manufacture or sale of non-halal products, conventional insurance, and entertainment activities which are non-permissible according to the Shari ${ }^{\prime} a h$ law, as well as the nature of the counter-party's (firm's) business (Derigs and Marzban, 2008). As a consequence, any company that has its transaction involving its core-business to include one of the non-permissible activities will be classified as Shari ah non-compliant. On the other hand, the quantitative parameter is used to measure the level of mixed contributions of the permissible and the non-permissible activities towards the revenue and the profit of the company (Jamal et al., 2010). Wherein, the quantitative approach also requires that the contribution of a non-permissible activity must not exceed the permissible benchmark (Pok, 2012). In general, this method involves four main financial ratios of screening namely, i) the liquidity ratio, ii) the receivable ratio, iii) the debt ratio and, iv) the interest income ratio as illustrated in Table 1.3 below (Khatkhatay \& Nisar, 2007).

A number of studies have successively used different conceptual and methodological approaches to model equity prices or returns on financial markets. The existing financial literature shows that the movement of the equity price as a consequence of the movement of 
the micro and macroeconomic factors. According to the economics theory, the relationship between the micro and the macroeconomic factors may have been derived from the fact that the micro-economics is highly related with the investor's individual behaviour which can be subjected to deductive reasoning, whim and fancy, while the macroeconomic focuses on the systematic behaviour (Akdeniz \& Milliken, 1975). The bottom line is that the microeconomic analysis utilizes a bottoms-up approach when individual cases are to be examined, while the macroeconomic utilizes a top-down approach where aggregate entities are involved (Becker, 2006). Thus, both approaches help in analysing the performance of the industry and economy as a whole. If the decision makers ignore one and lay emphasis on the other, it will lead to wrong or inadequate decisions and the decision may be considered to be only half decision-making. In financial literature a lot of studies have been investigated the relationship between macroeconomic fundamentals and equity prices behaviours, however, few studies had made an effort to the micro level relationship. Therefore, the present study give more focuses on micro level analysis of the unit trust industry to understand how funds operate and fix their prices.

Microeconomic analysis helps to investigate how individual prices are set by understanding the factors that have an impact on the decisions made by the individuals and the groups of investors, since the microeconomic decisions made by firms or individuals are usually motivated by cost and benefit considerations. Therefore, it is relevantly useful for the investors and fund's managers of the Islamic equity unit trust funds to involve these benefits and the funds' characteristics as indicators for individual equity fund in order to measure its performance and determine the behaviours of its price. Thus, the relationships between NAV of Islamic equity funds and microeconomic variables, namely, Income Distributions (dividends) (DIV), Historical Performance (HP), Fund Risk (S), Fund Size (FZ), Fund Management Experience (MEX), and Hedge Funds (HF) are investigated in this study. In an effort to achieve the stated objectives, the study aims to answer the following research question:

I. Do the chosen microeconomic variables all share significant long-run equilibrium relationships with the equity unit trust funds units' prices proxied by the general NAV index?

The rest of this paper is organized as follows: Section 2 reviews previous literature of relationship between microeconomic factors and equity market prices, Section 3 and 4 describes the data $\&$ methodology applied in the research analysis. Section 5 discussed the empirical results and finally section 6 draw the conclusion.

\section{Literature Review}

The existing literature on the equity market show that the price efficiency of equity market has been examined by studying the relationships between the micro, macroeconomic factors and the equity share prices (Aug \& Chiona, 2010; Shubiri, 2010; Nazir et al., 2010; Buyuksalvarci, 2010; and Pilinkus, 2010). Govindarajan et al., 2012 documented that Equity share price volatility is generally related with the internal and the external factors. Internal factors can be classified as microeconomic factors that are related to the individual operation 
of the firms- capital expenditure, company management, insider trading, dividend policy, company share and value in the sector (Özlen \& Ergun, 2012). The obtainable literature on the effect of microeconomic factors on equity prices such as Irfan and Nishat (2002), Low (2007), Shubiri (2010), Khan et al. (2011), Irmala et al. (2011), Ali (2011), Özlen and Ergun (2012), See \& Jusoh (2012), and Shah et al. (2012) showed that there are many internal variables that affect the companies or funds' performance in equity market which in turn impact the price level. For instances, dividend yield, dividend announcement, earning per share, management performance, risk's volatility, credibility, and size and capital growth of the firms or fund portfolios size.

\section{Data}

Monthly data of 30 Islamic equity unit trust funds have been used in the study analysis over the period January 2006 to December 2012 which collected from the secondary sources. In particular, data on the monthly NAV of the Islamic equity unit trust funds and fund size (total asset), dividends and risks of each equity unit trust fund and hedge fund index were obtained from the Bloomberg data-base. While data of the historical performance of each individual fund were gathered from the Eurekahedge Fund data-base. Data of management experience was obtained from the respective websites of each individual management company of the unit trust funds. The set of micro-economic variables, such as the NAV, DIV, HP, S and FZ were calculated based on the weighted average of portfolio size, however, the MEX variable was calculated based on the normal mean of the experience of 30 Islamic fund managers. In addition, the set of microeconomic variables, which are FZ, MEX, and HF, were transformed into the natural logarithm except the variables that contain zero and decimal values, such as the NAV, DIV, HP, and S.

\section{Methodology}

This study employed the recently-proposed autoregressive distributed lag model (ARDL) proposed by Pesaran and Shin (1995/1997), which includes lag determinants, the Bound-test and long-run and short-run estimation of the variables coefficients using Microfit 4.1 software. More modern studies have shown that the ARDL approach to cointegration is more appropriate than other conventional cointegration approaches such as Engle and Granger (1987), Johansen (1988), Johansen and Juselius (1990) and Gregory and Hansen (1996). One of the motives for favouring the ARDL approach is that it is applicable irrespective of whether the underlying regressors are purely $I(0)$, purely $I(1)$ or mutually cointegrated. This means the ARDL model avoids problems resulting from non-stationary time series data (Pesaran et al., 1996 and Pesaran et al. 2001). Another motivation of using the ARDL model is because it is more robust and achieves better result for small sample sizes (as the case of this study) than other cointegration techniques (Narayan, 2004).

\subsection{Lag Determinants}

One of the most important issues in applying the ARDL model is the choice of lags to be included. The Microfit will select the lag order of an ARDL model (equation (4.1)) bellow for each variable $(\mathrm{m} 1, \mathrm{~m} 2, \mathrm{~m} 3, \mathrm{~m} 4, \mathrm{~m} 5, \mathrm{~m} 6, \mathrm{~m} 7)$ by searching the $(p+1)^{\mathrm{k}+1}$ different ARDL 
models in order to obtain the optimal lag length for each variable, where $p$ represents the maximum number of lags to be used and $k$ represents the number of regressors in the equation. The selection of the lag order is made based on several criteria namely, $\bar{R}^{2}$ Criterion, Schwarz Bayesian Criterion (SBC), Akaike Information Criterion (AIC) and Hannan-Quinn Criterion (HQC). However, this study used only AIC and SBC criteria as they are commonly used in the literature.

The estimated unrestricted error correction model (UECM) of the ARDL model is formulated as follow:

$$
\begin{gathered}
\Delta \mathrm{NAV}_{t}= \\
\alpha_{0}+\alpha_{1} t+\sum_{i=1}^{p-1} b_{i} \Delta \mathrm{NAV}_{t-i}+\sum_{i=0}^{p-1} d_{i} \Delta \mathrm{DIV}_{t-i}+\sum_{i=0}^{p-1} e_{i} \Delta \mathrm{HP}_{t-i}+\sum_{i=0}^{p-1} f_{i} \Delta \mathrm{S}_{t-i}+ \\
\sum_{i=0}^{p-1} g_{i} \Delta \mathrm{LFZ}_{t-i}+\sum_{i=0}^{p-1} k_{i} \Delta \mathrm{LMEX}_{t-i}+\sum_{i=0}^{p-1} l_{i} \Delta \mathrm{LHF}_{t-i}+\delta_{1} \mathrm{NAV}_{t-1}+\delta_{2} \mathrm{DIV}_{t-1}+ \\
\delta_{3} \mathrm{HP}_{t-1}+\delta_{4} \mathrm{~S}_{t-1}+\delta_{5} \mathrm{LFZ}_{t-1}+\delta_{6} \mathrm{LMEX}_{t-1}+\delta_{7} \mathrm{LHF}_{t-1}+\mu_{t}
\end{gathered}
$$

Where, $\triangle \mathrm{NAV}, \triangle \mathrm{DIV}, \Delta \mathrm{HP}, \Delta \mathrm{S}, \Delta \mathrm{LFZ}, \triangle \mathrm{LMEX}, \triangle \mathrm{LHF}$ are the first difference of the variables. $\alpha_{0}$ represents the constant term, $\alpha_{1} t$ the intercept and time trend that may be added, $\mathrm{p}$ represents the maximum number of lags order, $\mathrm{t}$ - denotes the time, while the $\left(b_{i}, d_{i}, e_{i}, f_{i}, g_{i}, k_{i}, l_{i}\right) \quad$ represent the coefficient of the first difference variables of the short run parameters. The second part (terms $\delta$ ) correspond to coefficient to the long-run relationship, and finally the $\mu_{t}$ denotes white noise residual.

\subsection{Testing for Cointegration: "The Bound Test}

The existence of the long-run relation between variables under investigation will be tested by computing the $F$-statistics for testing the significance of the lagged levels of the variables in the conditional unrestricted error-correction form of the underling ARDL model equation (4.1). The null and alternative hypotheses are stated as; in the null hypothesis, non-existence of long-run relationship among the variables in the model. The alternative hypothesis is the existence of the long-run relationship between the identified variables in the model. This is statistically represented by:

$$
\begin{aligned}
& \mathbf{H}_{0}: \quad \delta_{1}=\delta_{2}=\delta_{3}=\delta_{4}=\delta_{5}=\delta_{6}=\delta_{7}=0 \\
& \mathbf{H} 1: \delta_{1} \neq 0, \delta_{2} \neq 0, \delta_{3} \neq 0, \delta_{4} \neq 0, \delta_{5} \neq 0, \delta_{6} \neq 0, \delta_{7} \neq 0
\end{aligned}
$$

The computed $F$-statistic value will be evaluated with the critical values tabulated in Narayan (2004), since the number of observation is more than 30 observation. If the value of $F$-statistic lies above the upper bound critical value for a given significance level; the decision is that there exists long-run relationship between the dependent variable and the exploratory variables. If the value of the $F$-statistic falls below the lower bound critical value, the inference is that there is no long-run relationship between exploratory variables and the dependent variable. However, if computed $F$-statistic falls within lower and upper bound, then the results are inconclusive. (Narayan, 2004). 


\subsection{Long Run and Short Run Dynamics}

At this stage, if the long run relationship (coinegration) is established based on the Bound test, then the long run relationship of micro level will be estimated using the following ARDL ( $\mathrm{m} 1$, $\mathrm{m} 2, \mathrm{~m} 3, \mathrm{~m} 4, \mathrm{~m} 5, \mathrm{~m} 6, \mathrm{~m} 7)$ model:

$$
\begin{aligned}
& \mathrm{NAV}_{t}=\alpha_{0}+\sum_{i=1}^{m 1} \alpha_{1} \mathrm{NAV}_{t-i}+\sum_{i=0}^{m 2} \alpha_{2} \mathrm{DIV}_{t-i}+\sum_{i=0}^{m 3} \alpha_{3} \mathrm{HP}_{t-i}+\sum_{i=0}^{m 4} \alpha_{4} \mathrm{~S}_{t-i}+ \\
& \sum_{i=0}^{m 5} \alpha_{5} \mathrm{LFZ}_{t-i}+\sum_{i=0}^{m 6} \alpha_{6} \mathrm{LMEX}_{t-i}+\sum_{i=0}^{m 7} \alpha_{7} \mathrm{LHF}_{t-i}+\omega_{t}
\end{aligned}
$$

Where $\alpha_{0}$ denotes the constants term, $\alpha_{1} \ldots \alpha_{7}$ denotes the coefficient of the long-run relationships of the variables, $\left(m_{1}, m_{2}, m_{3}, m_{4}, m_{5}, m_{6}\right.$, and $\left.m_{7}\right)$ represents the lag orders for each individual variable in the model, $\omega_{t}$ represents the white noise residual and $t$ - denotes the time.

The next step is to construct Error Correction Model (ECM) recommended by Pesaran, Shin and Smith (2001). When a long run relationship between variable sexist, an error correction term that adjusts back the system to the long run equilibrium after a short-run shock disturbance should be exist. The short-run coefficients can be derived by constructing an Error Correction Model of the following formula:

$$
\begin{aligned}
& \Delta \mathrm{NAV}_{t}=\beta_{0}+\sum_{i=1}^{p-1} \beta_{1} \Delta \mathrm{NAV}_{t-i}+\sum_{i=0}^{p-1} \beta_{2} \Delta \mathrm{DIV}_{t-i}+\sum_{i=0}^{p-1} \beta_{3} \Delta \mathrm{HP}_{t-i}+\sum_{i=0}^{p-1} \beta_{4} \Delta \mathrm{S}_{t-i}+ \\
& \sum_{i=0}^{p-1} \beta_{5} \Delta \mathrm{LFZ}_{t-i}+\sum_{i=0}^{p-1} \beta_{6} \Delta \mathrm{LMEX}_{t-i}+\sum_{i=0}^{p-1} \beta_{7} \Delta \mathrm{LHF}_{t-i}+\psi E C M_{t-1}+\vartheta_{t}
\end{aligned}
$$

Where, all variables are as previously defined, $\beta_{0}$ represents the constant term, $\beta_{1} \ldots \beta_{7}$ denotes the coefficient of the first difference variables, $\psi$ represents adjustment coefficient of the error term $\left(E C M_{t-1}\right)$, which derived from the long-run relationship estimated in model (4.3). $P$ represents the maximum number of lags lengths, $\vartheta_{t}$ denotes the white noise residual, and $t$ - denotes the time.

\subsection{Diagnostics tests}

Finally, in order to establish the validity and stability of the ARDL model, sensitivity analysis must be conducted. This included LM-test, to make sure that there is no serial correlation among the regressors, functional form test to confirm the model is properly specified, normality test to show the residuals are normally distributed and heteroscedasticity test to check if the model is free from heteroscedasticity and the ARCH effect. The stability test was also conducted by using the Cumulative Sum of Recursive Residuals (CUSUM), and Cumulative Sum of Squares of Recursive residuals (CUSUMsq) to confirm that the model is stable. 


\section{Empirical Results}

The empirical results of the study contains correlation matrix results, unit root test results, selecting the optimal lag-lengths, bond-test results and long and short-run coefficient estimations.

\subsection{Correlation Matrix Results}

There are two main functions for the correlation matrix test: i) to show the coefficients of correlation between all the pairs of variables and ii) to identify if there is multicollinearity among the independent variables. The correlation analyses results are reported in Table 5.1 below.

Table 5.1. Pairwise Correlation of the Micro-Economic Variables under Study

\begin{tabular}{lccccccc}
\hline & NAV & DIV & HP & S & LFZ & LMEX & LHF \\
\hline NAV & 1 & & & & & & \\
DIV & $0.148^{*}$ & 1 & & & & & \\
HP & $0.173^{*}$ & $-0.097^{*}$ & 1 & & & & \\
S & $0.216^{* *}$ & $0.196^{* *}$ & $-0.186^{*}$ & 1 & & & \\
LFZ & $0.434^{* *}$ & -0.001 & 0.014 & $-0.204^{* *}$ & 1 & & \\
LMEX & $0.292^{* *}$ & -0.023 & $-0.076^{*}$ & $-0.174^{*}$ & $0.958^{* * *}$ & 1 & \\
LHF & $0.543^{* *}$ & $0.175^{*}$ & 0.002 & $0.391^{* *}$ & $-0.428^{* *}$ & $-0.502^{* *}$ & 1
\end{tabular}

Note: '***', '**', and '*' denote significance at the 1\%, 5\%, and 10\% levels, respectively. NAV = Net Asset Value, DIV $=$ Dividends, $S=$ funds Risk, LFZ = natural Logarithm of Fund Size, LMEX = natural Logarithm of Management Experience, $L H F=$ natural Logarithm of Hedge Funds

The correlation matrix results show that all the variables in the model shows satisfactory relationship except for the DIV with LFZ, HP, and LMEX. An insignificant correlation between DIV and LFZ suggest that the fund value is improved by investing in productive assets and not by distributing income to unit-holders. This result is supported by Miller \& Modigliani (1961) who advocated that the dividend policy of the firm does not affect or determine its value; the only thing that could affect the value of firm is the investment policy. Furthermore, Table 5.1 displays an insignificant negative correlation between DIV and HP in the unit trust fund investment, which means that dividend policies are irrelevant as determinants of the fund performance. Thus, fund managers should give sufficient time to designing a dividend policy that helps to enhance fund performance, and, therefore, the unit-holders' investment value. DIV also has an insignificant negative correlation of -0.023 with management experience (LMEX). This may depict that as managers gain flexibility with experience to invest in unit trust investment schemes they tend not to distribute dividends, since a higher dividend pay-out may mean fewer funds available for investment, which may restrict and reduce the performance of the fund manager in the market.

More so, the correlation matrix results in Table 5.1 reveal that there is a strong positive correlation between the fund size and the management experience at 0.958 . This is perhaps 
because, as managers gain more experience they obtain more knowledge about the investment in the unit trust industry, and gain more confidence in their own abilities, it gives them the priority to manage the large funds in the industry. However, the high correlation between these two variables does not mean that they represent each other in the model, as, in statistics, it is called redundant information (Multicollinearity). In the case of collinearity, usually, when the decision is made to drop one of the redundant variables the adjusted R-square keeps nearly constant, however, for example, as the current study tries to drop one of these two variables the adjusted R-square drops by more the 70 per cent. This indicates that these variables do not have causality effect between them and that they may only have an association relationship. In other words, these two variables have a complementary relationship, whereby both factors (human capital and capital market) must exist in order to run the unit trust business. Therefore, the decision made in this study is to keep both variables in the model for further analysis.

\subsection{Unit Root Test Results}

The ARDL model can be applied irrespective of whether the regressors are purely $I(1)$ and purely $I(0)$ or mutually cointegrated. However, the necessity for conducting the stationary test is to confirm that none of the variables is integrated of order two or I (2) (Sultan, 2010). To this end, two different unit root tests are employed - the Augmented Dickey-Fuller (1979) (ADF) unit root test, and the Phillips-Perron (1988) (PP) unit root test. The results of the unit root test are presented in Table 5.2 bellow.

Table 5.2. Unit Root test for the NAV and Micro-Economic Variables

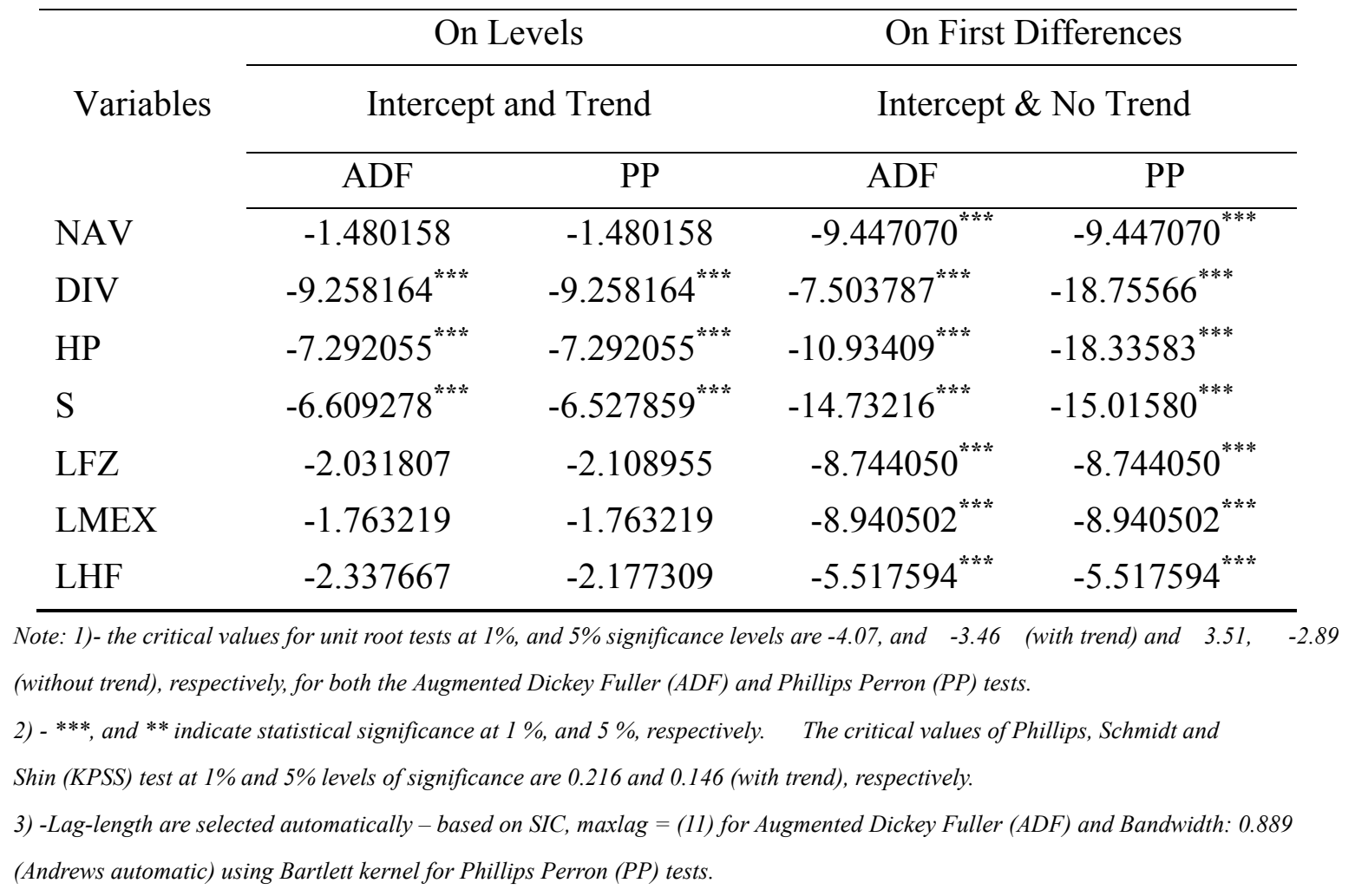

The findings indicate that micro-economic variables, such as DIV, HP, and S are stationary in level at the 1 per cent level of significance. However, the NAV of the Islamic equity unit trust 
funds and the other micro-economic variables, namely, the LFZ, LMEX and the LHF are all stationary on first differencing at the 1 per cent level of significance, on the basis of both the ADF and the PP unit root tests.

\subsection{Determinants of the Optimal Lag}

This study carries out the OLS regression from lag 1 until lag 12 since the study involves monthly data. However, due to the limited number of observations in this study, it only allowed the inclusion of a maximum of eight lags in the model. The results are given in Tables 5.3 and 5.4 below:

Table 5.3. Selecting the Lag Order (Restricted intercept and no trend)

\begin{tabular}{rccll}
\hline$P$ & $\mathrm{AIC}$ & $\mathrm{SBC}$ & \multicolumn{1}{c}{$x_{s c}^{2}(1)$} & \multicolumn{1}{c}{$x_{s c}^{2}(4)$} \\
\hline 1 & 184.172 & 166.1217 & 1.0246 & $15.1991^{* * *}$ \\
$\mathbf{2}$ & $\mathbf{1 8 7 . 3 2 7}$ & $\mathbf{1 6 0 . 9 8 8}$ & $\mathbf{0 . 0 0 9 6 3 4}$ & $\mathbf{4 . 2 1 2 5}$ \\
3 & 186.0156 & 151.4762 & 2.2821 & 4.9617 \\
4 & 180.7685 & 138.1184 & 0.069781 & 4.0111 \\
5 & 173.2512 & 122.5819 & 2.5622 & $8.4408^{*}$ \\
6 & 170.0954 & 111.5003 & 0.40808 & $17.5191 * * *$ \\
7 & 166.8645 & 100.4386 & 0.40918 & $26.6114^{* * *}$ \\
8 & 169.5362 & 95.3766 & $29.9658 * * *$ & $56.1293 * * *$ \\
\hline Note: '***,' '**'and '*'denote significance at $1 \%, 5 \%$ and 10\% levels, respectively
\end{tabular}

Table 5.4. Selecting the Lag Order (Restricted intercept with time trend)

\begin{tabular}{cllll}
\hline$P$ & AIC & SBC & \multicolumn{1}{c}{$x_{S C}^{2}(1)$} & \multicolumn{1}{c}{$x_{S c}^{2}(4)$} \\
\hline 1 & 183.684 & 164.4302 & 1.7257 & $14.2228^{* * *}$ \\
$\mathbf{2}$ & $\mathbf{1 8 6 . 7 9 7 7}$ & $\mathbf{1 5 9 . 2 6 1 5}$ & $\mathbf{0 . 0 3 9 9 8 2}$ & $\mathbf{3 . 9 6 9 8}$ \\
3 & 185.0689 & 149.3385 & $2.7981^{*}$ & 5.2092 \\
4 & 179.8532 & 136.0184 & 0.11533 & 4.166 \\
5 & 172.6514 & 120.8039 & $2.9664 *$ & $10.0576^{* *}$ \\
6 & 169.0957 & 109.3287 & 0.4573 & $17.5549 * * *$ \\
7 & 166.0279 & 98.4367 & 0.76409 & $27.3518^{* * *}$ \\
8 & 172.1163 & 96.7979 & $21.8856^{* * *}$ & $57.6906 * * *$ \\
\hline Note: ‘**', ‘**' and ‘*’ denote significance at $1 \%, 5 \%$ and $10 \%$ levels, respectively
\end{tabular}

In Tables 5.3 and 5.4, ' $p$ ' represents the lag order and AIC and SBC represent the Akaike and Schwarz information criterions, respectively. In addition, $x_{s c}^{2}(1)$ and $x_{s c}^{2}(4)$ are the Breusch Godfrey error terms Lagrange multiplier serial correlation test. The $x_{s c}^{2}$ values indicate whether the null hypothesis of no serial correlation at orders 1 and 4 exists. The overall results suggest that the best model with no serial correlation problem is the one that uses two lag-lengths, as confirmed by the highest value based on AIC, which are 187.327 and 186.7977, for both situations, without and with time trend, respectively. Therefore, this study 


\section{Macrothink}

follows the AIC criterion model due to the lag order selected by the AIC, irrespective of whether or not a deterministic time trend term is included because the AIC is much larger than that selected by the SBC criterion.

\subsection{Bounds-Test Results}

In this stage, the presence of a potential cointegration relationship between the NAV of the Islamic equity unit trust funds and its micro-economic determinants is examined. This is done by applying the bounds test through comparing the $F$-statistic value with the critical bounds value provided by Narayan (2004) for both cases: a) restricted intercept and not trend (case II), and b) restricted intercept and time trend (case III), as reported in Table 5.5 below. The calculated $F$-statistic values based on (UECM) are 3.5972 without determining the time trend (Appendix IV) and 3.6678 with the time trend (Appendix V). Since the $F$-statistic values are outside the critical bounds value, it can be concluded that the null of no cointegration can be rejected at the 5 per cent level of significance in case (II). However, in the case where the time trend is determined, the null hypothesis of no cointegration is rejected only at the 10 per cent level of significance. Thus, this study will continue the analysis using case (II). Hence, we can conclude that the NAV of the Islamic equity unit trust funds and its micro-economic determinants are found to be integrated in the long run.

Table 5.5. Critical Values for the F-test $(k=7, n=59)$

\begin{tabular}{lll|cc}
\hline \multicolumn{3}{c|}{ Case II } & \multicolumn{2}{c}{ Case III } \\
\multicolumn{2}{l}{ (Restricted intercept and not trend) } & (Restricted intercept and time trend) \\
\hline S.level & $\mathbf{I}(\mathbf{0})$ & $\mathbf{I}(\mathbf{1})$ & $\mathbf{I}(\mathbf{0})$ & I(1) \\
\hline $1 \%$ & 3.129 & 4.507 & 3.346 & 4.895 \\
$5 \%$ & 2.373 & 3.540 & 2.513 & 3.823 \\
$10 \%$ & 2.044 & 3.104 & 2.155 & 3.353 \\
\hline
\end{tabular}

Source: Narayan (2004).

\subsection{Long-Run Coefficients Estimation}

The long-run test statistics (Table 5.6) indicate that all the explanatory variables have statistical significant relationship with the NAV of the Islamic equity unit trust fund except the funds' risk and the fund management experiences. 
Table 5.6. Estimated Long-Run Coefficients using the ARDL Approach, ARDL (2, 0, 2, 1, 2, $0,1)$ Selected Based on AIC Criterion, Dependent Variable is NAV

\begin{tabular}{lccr}
\hline Regressor & Coefficient & Standard Error & T-Ratio[Prob] \\
\hline DIV & -6.9668 & 3.3651 & $-2.0703^{* *}$ \\
HP & .098320 & 0.040057 & $2.4545^{* *}$ \\
S & -3.1397 & 4.1911 & -0.74913 \\
LFZ & .37850 & 0.11226 & $3.3716^{* * *}$ \\
LMEX & -.94060 & 0.56166 & -1.6747 \\
LHF & 1.1623 & 0.23124 & $5.0263^{* * *}$ \\
Constant & -5.1668 & 3.1345 & -1.6484 \\
\hline \multicolumn{2}{c}{ Note: '***', '**' '*'and denote significance at 1\%, 5\%, 10\% respectively. }
\end{tabular}

In particular, the dividends policy has a negative statistical relationship with the NAV of the Islamic equity unit trust funds at the 5 per cent level of significance. This negative effect is because the income earned by the unit trust fund during the financial year is accrued in its unit's price of funds until the end of the distribution period. Upon declaration of an income distribution, dividends or capital gains are paid out to unit-holders. The NAV of the Islamic funds will tend to drop by approximately the same amount as the income distributed. However, the funds' unit price will return and increase if the fund continues doing well in the market.

Evidence is provided by Wermers, Wu, Zechner (2005) who investigated the rationality of closed-end fund discounts. They advocated that on the ex-dividend day, the fund's stock price and fund NAV mechanically drop by the same amount of cash distribution (capital gains and dividends), but that the resulting change in the discount is purely mechanical and has no effect on the return to shareholders. Thus, new investors are advised to buy the fund units immediately after the dividend pay-out, and then hold the units during the financial year to obtain capital gain and make a decision to sell their units before any announcement of income distribution.

Moreover, the results in Table 5.6 indicate that there is a statistically significant positive relationship between the NAV of the Islamic equity unit trust funds and their past performance. This result reflects the existence of performance persisting over time. The rational justification behind this positive relationship is that the ranking of the equity unit trust funds in the market is based on previous performance records, which are carefully analysed by both market practitioners and investors. Accordingly, investors habitually believe that funds that had a satisfactory performance record in the past will continue to do so in the future. Thus, funds that record positive persistence in the past will have a higher chance of attracting huge net inflows, which, in turn, lead to increase the fund unit price. This finding is in line with the results of the study by Hendricks et al. (1993) who found stronger evidence that funds that do well in the past do well in the short-term future. Further, this is supported by Goetzmann and Ibbotson (1994), who suggested that past mutual fund returns could predict future returns. Thus, the past performance must be considered by potential investors 
to determine whether past performance (good or bad) can help in the prediction of future performance.

Table 5.6 also shows a statistically insignificant negative relationship between the NAV of the Islamic equity funds and the fund risk, which indicates that Islamic equity funds in Malaysia are relatively well diversified. This finding is possible, as the fund's portfolio can spread the risk through investing in a large number of securities since it combines the financial resources of a large pool of investors. This result concurs with the findings from Tse and Chia (1997) and Koh, Mitchell and Fong (2010), who examined whether the unit trusts are sufficiently diversified in Singapore. Their findings indicated that unit trusts are well diversified and that the systematic risk is eliminated and reduced to some degree. The results of the current study therefore suggest that Islamic equity unit trusts do help investors diversify their portfolio risk, which is particularly helpful for small investors.

Table 5.6 presents a positive significant relationship between the NAV of the Islamic equity unit trust fund and fund size. The evidence of a positive influence of fund size on the NAV can in fact be determined through the fund performance. This means that larger funds take advantage of economies of scale through spreading higher transaction costs over a larger asset base, which, in turn, leads to improved and better performance. In addition, when the fund portfolio has a large size this will benefit in the spreading of risks over a wide variety of securities in different stock sectors, which, in turn, enhance the fund performance and its return. Study by Grinblatt and Titman (1989), and Otten and Bams (2001) provide evidence that a large fund size positively influences the performance of the funds. Similarly, Ferreira and Matos (2006) studied the performance of international mutual funds for 19 countries over the period 1999 to 2005; their results show that good and high performance occurs among large funds. However, other researchers, such as Perold and Jr (1991), and Lowenstein (1997) believe that a large asset base erodes the performance of the fund due to the costs of trading associated with liquidity or price impact. Thus, fund managers should monitor their fund size regularly, since the fund size tends to fluctuate over the years, inasmuch as there is a maximum fund size after which performance declines as the fund size increases (Detzel, 2006 and Xiong et al., 2009).

In Table 5.6, the estimated coefficient of the management experience (LMEX) shows a statistically insignificant negative effect on the NAV of the Islamic equity unit trust funds even at 10 per cent level of significance. This insignificant relationship may be explained in two ways, a) the lack of timing skills and stock selecting ability of the fund managers, or b) the poor money management performance, as it is measured by the risk-adjust returns. A further explanation for this result is that skilled analysts get bid away once they build a track record (Silli, 2006). This means that once a fund manager's reputation is established managers sit back and the increased reward of good managers put away any additional effort or value created by their skill or experience. The results of this study coincide with most of the studies such as Shamsher and Annuar (1995), Leong and Aw (1997), Nassir, Mohamed and Ngu (1997), Low and Ghazali (2005), Taib and Isa (2007) and Low (2007), whose studies evaluated the overall fund performance, divided the fund performance into selectivity and market timing modules. The overall results revealed that managers show poor selectivity 


\section{Macrothink}

performance and that managers' market timing activities do not add value to the funds' return.

Table 5.6 indicates that the hedge fund index has a statistically significant positive effect on the NAV of the Islamic equity unit trust fund in the Malaysian unit trust industry. This is because the characteristics and investment strategy of hedge funds allow for a short-term investment horizon, usually a year or less. Hence, fund managers of Islamic equity funds take this opportunity to invest their access liquidity for short-term investment in order to reduce portfolio volatility risk and enhance their portfolio returns. Thus, when the hedge funds' investments yield a positive return, the Islamic equity funds will receive their income, resulting in an increase in the value of the funds' units.

In addition, hedge funds have become a successful investment vehicle that operates through alternative investment styles that are in line with Sharīah rules. For example, trade in derivatives, deal in futures and commodities, buy and sell options, and leverage their portfolios through certain Islamic contracts (Siddiqui, 1999). Thus, the advantages offered by hedge fund investments, enable the fund managers of Islamic equity funds to run the funds' transactions according to the Shari ${ }^{\prime}$ ah principles while making short-term returns. Thus, it is suggested that investors have to consider the movement of the hedge fund index when they make a decision to buy or sell and even hold the unit in their portfolios since the fund managers invest their money in hedge fund investments.

\subsection{Short-Run Estimation}

After accepting the long-run coefficients of the NAV equation, the next step is to do the error correction version of the ARDL model. Specifically, the ECM coefficient shows how quickly/slowly the relationship among the variables returns to its equilibrium path in the long-run (Waliullah \& Rabbi 2011), which should have a negative sign with a statistically significant coefficient. The results of the short-run coefficient estimates obtained are reported in Table 5.7 below. 


\section{Macrothink}

Table 5.7. Error Correction Representation for the Selected ARDL Model, $(2,0,2,1,2,0,1)$ Selected Based on (AIC) Criterion

\begin{tabular}{lrrr}
\hline Regressor & Coefficient & $\begin{array}{r}\text { Standard } \\
\text { Error }\end{array}$ & T-Ratio \\
\hline$\Delta$ NAV1 & -0.28935 & 0.10316 & $-2.8048 * * *$ \\
$\Delta$ DIV & -0.56556 & 0.14495 & $-3.9018 * * *$ \\
$\Delta \mathrm{HP}$ & 0.0063779 & 0.000042 & $15.1961 * * *$ \\
$\Delta \mathrm{HP} 1$ & 0.000534 & 0.0000288 & 1.8537 \\
$\Delta \mathrm{S}$ & 0.25745 & 0.20823 & 1.2364 \\
$\Delta \mathrm{LFZ}$ & 0.098612 & 0.032975 & $2.9905 * * *$ \\
$\Delta \mathrm{LFZ1}$ & -0.069851 & 0.031943 & $-2.1868 * *$ \\
$\Delta \mathrm{LMEX}$ & -0.076357 & 0.045006 & -1.6966 \\
$\Delta \mathrm{LHF}$ & -0.084062 & 0.080048 & -1.0501 \\
$\Delta \mathrm{INPT}$ & -0.41943 & 0.30908 & -1.3570 \\
ECM(-1) & -0.081179 & 0.032211 & $-2.5202 * *$ \\
\hline Note: '***', '**' and '*'denote significance at $1 \%, 5 \%$, and $10 \%$ respectively.
\end{tabular}

Goodness of fit indices

$\begin{array}{lc}\text { R-Squared } & 0.9298 \\ \text { R-Bar-Squared } & 0.91513 \\ \text { S.E. R } & 0.0082695 \\ \text { F( 10, 71) } 88.7397 & {[.000]} \\ \text { DW-statistic } & 2.2169\end{array}$

In Table 5.7, the Goodness of fit indices results show that chosen microeconomic factors are significantly determine the behaviour of NAV of the Islamic equity unit trust funds in Malaysian capital market, since the regression for the underlying ARDL equation is fitted very well at Adjust $\mathrm{R}^{2}=0.91513$. In addition, in Table 5.7 above, the error correction coefficient $\mathrm{ECM}_{t-1}$ is found to be negative and statistically significant at the 5 per cent level of significance. This further confirms the existence of a stable long-run relationship between the $\mathrm{NAV}$ and its micro-economic determinants. The coefficient of $\mathrm{ECM}_{\mathbf{t}-\mathbf{1}}$ is estimated as -0.081179 , which suggests a relatively slow adjustment process. In other words, it is only about 8 per cent of the disequilibria among the variables of the previous month's shock adjust back to the long-run equilibrium in the current month.

\subsection{Diagnostic Tests Results}

In order to determine the suitability of the ARDL model for examining the relationship between the NAV of the Islamic equity unit trust funds and its micro-economic determinants, the study applied a number of diagnostic tests to the ARDL model. The results of the diagnostic test are reported in Table 5.7 below. 


\section{Macrothink}

Table 5.7. Diagnostic Tests

\begin{tabular}{lcc}
\hline Test Statistics & \multicolumn{2}{c}{ LM Version } \\
\hline A: Serial Correlation & $x^{2}(12)=$ & $16.8824[.154]$ \\
B: Functional Form & $x^{2}(1)=$ & $2.0902[.148]$ \\
C: Normality & $x^{2}(2)=$ & $2.5355[.281]$ \\
D: Heteroscedasticity & $x^{2}(1)=$ & $.15873[.690]$ \\
\hline
\end{tabular}

Notes: The figures in the squared brackets [...] represent p-values of the statistical level of significance.

A: Lagrange multiplier test of residual serial correlation.

B: Ramsey's RESET test using the square of the fitted values.

C: Based on a test of skewness and kurtosis of residuals.

D: Based on the regression of squared residuals on squared fitted values.

Table 5.7 indicates that the outcomes of the ECM model passes all tests with no serial correlation, no specification in functional form, no heteroscedasticity or conditional autoregressive serial correlation, and the error term is normally distributed because all $x^{2}$ values are not significant. Furthermore, Figures 5.1 and 5.2 of the cumulative sum (CUSUM) and cumulative sum of squares (CUSUMsq), which plots from the recursive estimation of the ARDL model, show the stability of the long-run coefficients during the time frame of the study. The graphs for CUSUM and CUSUMsq do not go beyond the critical boundaries at the 5 per cent level of significance.

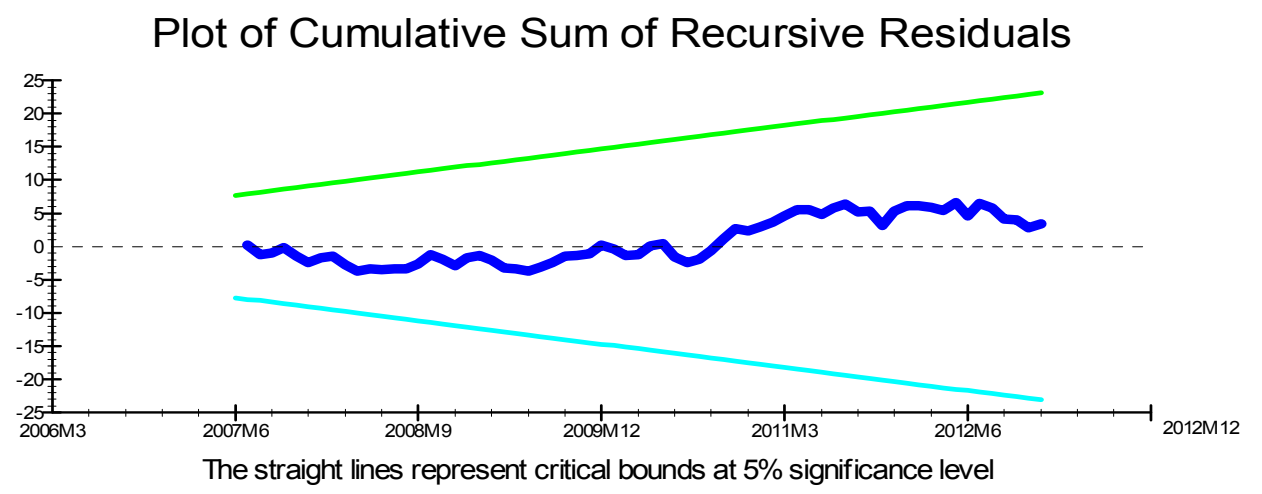

Figure 5.1. Plot of Cumulative Sum of Recursive Residuals 
Plot of Cumulative Sum of Squares of Recursive

Residuals

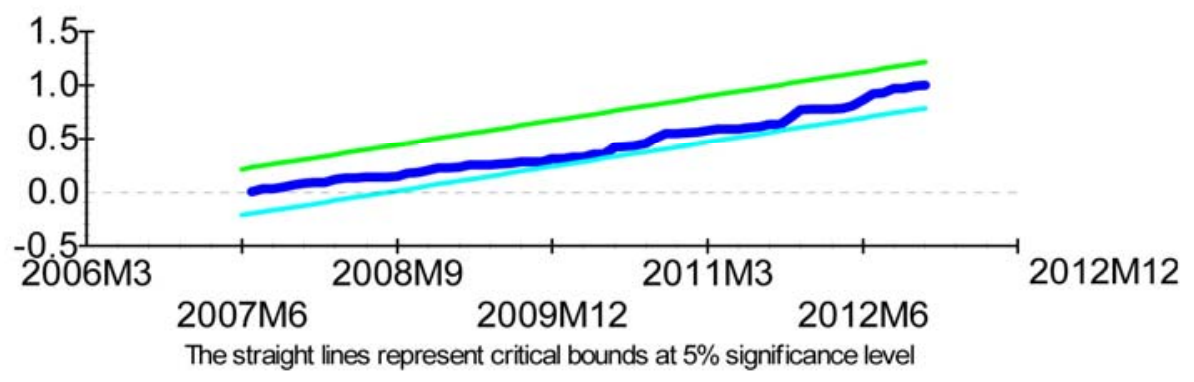

Figure 5.2. Plot of Cumulative Sum of Square Recursive Residuals

\section{Conclusion}

This study make an effort to investigate the microeconomic determinates of fund NAV of Islamic equity unit trust funds by select the variables that guided the investors' decisions to invest in the unit trust industry based on their risk and returns preference parameters (dividends, risk, and hedge fund) as well as the variables that captured the impact of the capital market (fund size) and human capital (management experiences). The selected microeconomic variables are fully scrutinized using the Autoregressive Distributed Lags (ARDL) model. The overall findings indicated that the NAV of the Islamic equity unit trust funds and the selected microeconomic variables shared a significant long run relationship in the Malaysian capital market except with two factors, which are funds management experiences and funds risks. This an indication that, in general, fund's managers in the Malaysian unit trust industry performed poorly in security analyses (stock selection ability) and market entry timing. However, they performed fairly well in risk-adjusted returns and typically maintained well-diversified portfolios. Thus, unit-holders have to study well the internal factors and fund characteristics before make their choice to select specific fund's unit in their portfolios investments.

However, to get a better consensus on the findings within the context of the Islamic Malaysian equity funds, more studies need to be done to find what funds characteristics other than already covered by the current study, can have any effect on the portfolio performance and the subsequent funds unit prices. The future study could be extended to variables, such as, funds managers' characteristics (i.e. qualification level, age, etc.), management fees and expenses, liquidity and trading costs as well as the investment strategies of the fund's portfolio structure, such as, asset allocation and investments style.

\section{Acknowledgement}

In the name of Allah SWT, the Most Gracious and the Most Merciful, the Authors would like to thank Almighty Allah SWT, for his blessings, encouragement and help to accomplish this research paper. At the same time, I would like to thank my supervisors Prof. Dr. Ahamed Kameel Mydin Meera and Prof. Dr. Hasanuddeen Abdul Aziz for their guidance, assistance, and valuable comments that improve the quality of this research paper.

\section{References}


Agu, C., \& Chukwuma-Agu, C. (2010). Shaky Pillars: Are Micro and Macroeconomic Fundamentals Enough to Explain the Strength of the NigeriaStock Exchange? International Research Journal of Finance and Economics, 4, 74-86.

Akdeniz, F., \& Milliken, G. A. (1975).The Relationship between Macro and Micro Parameters. International Economic Review, 16(2), 511-515. http://dx.doi.org/10.2307/2525829

Ali, M. B. (2011). Impact of Micro and Macroeconomic Variables on Emerging Stock Market Return: A Case on Dhaka Stock Exchange (DSE). Interdisciplinary Journal of Research in Business, 1, 08-16.

Becker, J. (2006). Metamorphosen der regionalen Integration. In: JEP, 22(2), 11-44.

Büyükşalvarc1, A. (2010). The Effects of Macroeconomics Variables on Stock Returns: Evidence from Turkey. European Journal of Social Sciences, 14(3), 404-416.

Derigs, U., \& Marzban, S. (2008). Review and Analysis of Current Shariah-Compliant Equity Screening Practices. International Journal of Islamic and Middle Eastern Finance and Management, 1(4), 285-303. http://dx.doi.org/10.1108/17538390810919600

Detzel, L. F. (2006). Determining a Mutual Fund's Equity Class. Financial Services Review, 15(3), 199-212.

Dickey, D., \& Fuller, W. (1979). Distributions of the Estimators for Autoregressive Time Series with a Unit Root. Journal of the American Statistical Association, 75, 427-431.

Engle, R. F., \& Granger, C. W. J. (1987). Cointegration and Error Correction: Representation $\begin{array}{llll}\text { Estimation and } \text { Testing. } & \text { Econometrica, } & 55 \text { 1-276. }\end{array}$ http://dx.doi.org/10.1108/17538390810919600s

Ferreira, M., \& Matos, P. (2006). The Colours of Investor Money: The Role of Institutional Investor around the World. Working Paper.

Goetzmann, W. N., \& Ibbotson, R. (1994). Do Winners Repeat? Patterns in Mutual Fund Behaviour. Journal of Portfolio Management, 20(2), 9-18. http://dx.doi.org/10.3905/jpm.1994.9

Govindarajan, K., Balachandran, S., Anand, V. V., \& Vijesh, R. (2012). A Study on Profit Maximisation in a Volatile Stock Market. International Research Journal of Finance and Economics, 94(7), 91-102.

Gregory, A.W. \& Hansen, B.E. (1992). Residual-Based Tests for Cointegration in Models with Regime Shifts. Working Papers No.335, University of Rochester - Center for Economic Research (RCER).

Grinblatt. M, \& Titman. S. (1989). Mutual Fund Performance: An Analysis of Quarterly Portfolio Holdings, Journal of Business, 62(3), 393-416. http://dx.doi.org/10.1086/296468 
Hendricks, D., Patel, J., \& Zeckhauser, R. (1993). Hot Hands in Mutual Funds: Short-Run Persistence of Relative Performance. Journal of Finance, 48(1), 93-130. http://dx.doi.org/10.1111/j.1540-6261.1993.tb04703.x

Irfan, C. M., \& Nishat, M. (2002). Key Fundamental Factors and Long-run Price Changes in an Emerging Market-A Case Study of Karachi Stock Exchange (KSE). The Pakistan Development Review, 41(4), 517-533.

Irmala, P. S., Sanju, P. S., \& Ramachandran, M. (2011).Determinants of Share Prices in India.Journal of Emerging Trends in Economics and Management Sciences, 2(2), 124-130.

Jamal, J., Hambali, N., \& Ali, H. M. (2010). Islamic Capital Market and Shari'ah Screening in Malaysia. International Conference on Research Symposium in Service Management, Le Meridien Hotel, Mauritius, 24-27 August 2010(1694-0938), 1-16.

Johansen, S. (1988). Statistical Analysis of Cointegrating Vectors. Journal of Economic Dynamics and Control, 12, 231-254. http://dx.doi.org/10.1016/0165-1889(88)90041-3

Johansen, S., \& Juselius, K. (1990). Maximum Likelihood Estimation and Inference on Cointegration-With Applications to the Demand for Money. Oxford Bulletin of Economics \& Statistics, 52(2), 169-210. http://dx.doi.org/10.1111/j.1468-0084.1990.mp52002003.x

Khan, K. I., Aamir, M., Qayyum, A., Nasir, A., \& Khan, M. I. (2011). Can Dividend Decisions Affect the Stock Prices: A Case of Dividend Paying Companies of KSE.International Research Journal of Finance and Economics, 76, 67-74.

Khatkhatay, M. H., \& Nisar, S. (2007). Shariah Compliant Equity Investments: An Assessment of Current Screening Norms. Islamic Economic Studies, 15(1), 47-76.

Koh, B. S. K., Mitchell, O. S., \& Fong, J. H. Y. (2010). Collective Investments for Pension Saving: Lessons from Singapore's Central Provident Fund Scheme. Paper presented at the Insurance and Risk Management.

Leong, K. H., \& Aw, M. W. (1997). Measuring Unit Trust Fund Performance Using Different Benchmarks. Capital Market Review, 5(2), 27-44.

Low, S. W. (2007). Malaysian Unit Trust Funds Performance during Up and Down Market Conditions: A comparison of Market Benchmark. Managerial Finance, 33(2), 154-166. http://dx.doi.org/10.1108/03074350710715863

Low, S.-W., \& Ghazali, N. A. (2005). An Evaluation of the Market-Timing and SecuritySelection Performance of Mutual Funds: The Case of Malaysia. International Journal of Management Studies, 12(1), 97-115.

Lowenstein, R. (1997). Frightened Funds: Is There a Master in the House?, Wall Street Journal. 20. p. C1.

Miller, M. H., \& Modigliani, F. (1961). Dividend Policy, Growth and Valuation of shares. Journal of Business 4(34), 411-433. http://dx.doi.org/10.1086/294442 
Narayan. P. K. (2004). Reformulating Critical Values for the Bounds F- statistics Approach to Cointegration: An Application to the Tourism Demand Model for Fiji. Department of Economics, Discussion Papers, No. 02/04, Monash University, Victoria 3800, Australia.

Nassir, A. M., Mohamed, S., \& Ngu, M. H. (1997). Selectivity and Timing: Evidence from the Performance of Malaysian Unit Trusts. Pertanika Journal of Social Science \& Humanities, 5(1), 45-57.

Nazir, M. S., Nawaz, M. M., Anwar, W., \& Ahmed, F. (2010). Determinants of Stock Price Volatility in Karachi Stock Exchange: The Mediating Role of Corporate Dividend Policy. International Research Journal of Finance and Economics, 55, 100-107.

Otten, R., \& Bams, D. (2001). European Mutual Fund Performance. European Financial Management, 8, 75-101. http://dx.doi.org/10.1111/1468-036X.00177

Özlen, S., \& Ergun, U. (2012). Internal Determinants of the Stock Price Movements on Sector Basis. International Research Journal of Finance and Economics, 92, 111-116.

Perold, A., \& Jr., R. S. S. (1991). The Right Amount of Assets under Management. Financial Analysts Journal, 47(3), 31-39. http://dx.doi.org/10.2469/faj.v47.n3.31

Pesaran, M. H., \& Shin, Y. (1995/1997). An Autoregressive Distributed Lag Modeling Approach to Cointegration Analysia.Paperpresented at the Symposim at the Centennial of Ragnar Frisch, The Norwegian Academy of Scinece and Letters, Oslo.

Pesaran, M. H., Shin, Y., \& Smith, R. (2001). Bounds Testing Approaches to the Analysis of Level Relationships. Journal of Applied Econometrics, 16, 289-326. http://dx.doi.org/10.1002/jae.616

Pesaran, M. H., Shin, Y., \& Smith, R. G. (1996). Testing for the Existence of a Long Run Relationship. Working Paper (9622), Department of Applied Economics, University of Cambridge.

Phillips, P. C. B., \& Perron, P. (1988). Testing for a Unit Root in Time Series Regression. Biometrika, 75, 335-346. http://dx.doi.org/10.1093/biomet/75.2.335

Pilinkus, D. (2009.). Stock Market and Macroeconomic Variables: Evidences from Lithuania. Economics \& Management, 14, 884-891.

Pok, W. C. (2012). Analysis of Syariah Quantitative Screening Norms among Malaysia Syariah-Compliant Stocks. Investment Management and Financial Innovations, 9(2), 69-80.

Sadeghi, M. (2008). Financial Performance of Shariah-Compliant Investment: Evidence from Malaysian Stock Market. International Research Journal of Finance and Economics, ISSN 1450-2887, 16-26.

See, Y. P., \& Jusoh, R. (2012). Fund Characteristics and Fund Performance: Evidence of Malaysian Mutual Funds. International Journal of Economics and Management Sciences, 1(9), $31-43$. 
Shah, I. U., Iqbal, J., \& Malik, M. F. (2012).Comparative Valuation between Islamic and Conventional Mutual Fund. International Research Journal of Finance and Economics, 96, 29-33.

Shamsher, M., \& Annuar, M. N. (1995). The Performance of Unit Trusts in Malaysia: Some Evidence. Capital Market Review, 3(2), 51-69.

Shubiri, F. N. A. (2010). Analysis the Determinants of Market Stock Price Movements: An Empirical Study of Jordanian Commercial Banks. International Journal of Business and Management, 5(10), 137-147.

Siddiqui, A. K. (1999.). The Hedge Fund, an Ideal Investment Vehicle for Muslim Investors. Paper presented at the Proceedings of the Second Harvard University Forum on Islamic Finance: Islamic Finance into the 21st Century, Cambridge, Massachusetts. Center for Middle Eastern Studies, Harvard University.

Silli, B. (2006). Modern Approaches in the Evaluation of Management Skill in the Mutual Fund Industry. Work paper. http://www.econ.upf.edu/ silli/Literature\%20Review\%20D2.pdf.

Sultan, R. (2010). Short-Run and Long-Run Elasticity of Gasoline Demand in Mauritius: An ARDL Bounds Test Approach. Journal of Emerging Trends in Economics and Management Sciences (JETEMS), 1(2), 90-95.

Taib, F. M., \& Isa, M. (2007).Malaysian Unit Trust Aggregate Performance. International Journal of Managerial $\quad$ Finance, $33(2), \quad$ 102-121. http://dx.doi.org/10.1108/03074350710715836

Tse, Y. K., \& Chia, J. H. H. (1997). An Empirical Analysis of Unit Trust Performance in Singapore. Working Paper, Singapore Management University.

Usmani, M.: (2002), An Introduction to Islamic Finance (Kluwer Law International, The Hague).

Wermers, R., Wu, Y., \& Zechner, J. (2005). Portfolio Performance, Discount Dynamics, and the Turnover of Closed-End Fund Managers. Work Paper. Department of Finance, University of Vienna: file://C:/Users/Anwar_1/Downloads/9fcfd5139eb45dfd86.pdf.

Waliullah, \& Rabbi, D. F. (2011). Effectiveness of Monetary Policy in Pakistan: Empirical Evidences based on Bound Test Approach. International Journal of Business and Social Science, 2(1), 190-199.

Xiong, J., Idzorek, T. M., Chen, P., \& Ibbotson, R. G. (2009). Impact of Size and Flows Performance for Funds of Hedge Funds. Journal of Portfolio Management, 35(2), 118-130. http://dx.doi.org/10.3905/JPM.2009.35.2.118

\section{Copyright Disclaimer}

Copyright for this article is retained by the author(s), with first publication rights granted to the journal. This is an open-access article distributed under the terms and conditions of the Creative Commons Attribution license (http://creativecommons.org/licenses/by/3.0/). 